\title{
ISOLASI DAN IDENTIFIKASI SENYAWA FLAVONOID DARI EKSTRAK ETANOL BUAH BELIMBING WULUH (Averrhoa bilimbiL.) DENGAN METODE SPEKTROFOTOMETRI UV-VIS
}

\section{ISOLATION AND IDENTIFICATION OF FLAVONOID COMPOUND FROM ETHANOL EXTRACT OF STARFRUITS (Averrhoa bilimbi L.) by USING SPECTROPHOTOMETRY UV-VIS METHOD}

\author{
Siti Hamdanah ${ }^{1 *}$, Syariful Anam ${ }^{1}$, Jamaluddin ${ }^{1}$ \\ ${ }^{1}$ Jurusan Farmasi, Fakultas MIPA, UniversitasTadulako, Palu, Indonesia.
}

Received 25 Januari 2015, Accepted 26 Februari 2015

\begin{abstract}
ABSTRAK
Buah belimbing wuluh (Averrhoa bilimbi L.) dari familia Oxalidaceae merupakan tanaman yang berpotensi sebagai antibakteri Staphylococcus aureus dan Escherichia coli. Flavonoid adalah senyawa aktif dari ekstrak buah belimbing wuluh yang berpotensi sebagai antibakteri. Buah belimbing wuluh diekstraksi dengan etanol $96 \%$ dengan cara maserasi. Ekstrak yang diperoleh diidentifikasi menggunakan Kromatografi Lapis Tipis (KLT) analitik dengan eluen n-butanol- asam asetat glasial - air (6;1:3). Isolasi secara KLT preparative menghasilkan 3 pita. Masingmasing pita tersebut disentrifuge sehingga diperoleh isolat. Isolat dianalisis secara fisika menggunakan spektrofotometer UV-Vis dan secara kimia menggunakan uji warna (perekasi geser). Hasil spektrum UV-Vis dengan pereaksi geser dari isolat 1 diduga merupakan senyawa isoflavon dengan gugus $\mathrm{OH}$ pada posisi 6,7,4' dan gugus o-di $\mathrm{OH}$ pada cincin $\mathrm{A}$, pada isolat 2 bukan merupakan senyawa flavonoid dan diperkirakan merupakan senyawa polifenol lain, serta pada isolat 3 diduga senyawa flavon dengan gugus $\mathrm{OH}$ pada posisi 5,6,7,4' dan gugus o-di OH pada cincin A.

Kata kunci : Averrhoa bilimbi L., Flavonoid, Spektrofotometer UV-Vis.
\end{abstract}

\begin{abstract}
Starfruits (Averrhoabilimbi L.) from family ofoxalidaceaeis a plant which has potential as an antibacterialStaphylococcus aureus and Escherichia coli.Flavonoid are the active compounds from the extract of starfruit which has potential as an antibacterial. Starfruit were extracting by ethanol $96 \%$ using maceration. Extract were identified using thin layer chromatography (TLC) with eluent analytic n-butanol- glacial acetic acid- water (6:1:3). Preparative isolation using thin layer chromatography resulting three bands. Each band was centrifuged to obtain isolates. Physics isolates were analyzing using spectrophotometer UV Vis and chemically using color test (shift reagent). UV Vis spectrum results with shift reagent from isolates 1, suspected as isoflavone compound with $\mathrm{OH}$ groups in position 6,7,4 and $\mathrm{OH}$ groups in $\mathrm{O}$ - ring $\mathrm{A}$, in isolates 2 was not flavonoid compound and predicted as other polyphenolic compound and in isolates 3 suspected of flavonecompound with $\mathrm{OH}$ groups in position 5,6,7 and $\mathrm{OH}$ groups in O-ring A.
\end{abstract}

Keywords : Averrhoa bilimbi L., Flavonoid, Spectrophotometer UV-Vis

* Corresponding author : Siti Hamdana, sitihamdana34@yahoo.co.id (ph: +62-852-4114-5288) 


\section{PENDAHULUAN}

Indonesia memiliki banyak jenis tanaman yang dapat dibudidayakan karena bermanfaat dan kegunaannya besar bagi manusia dalam hal pengobatan. Dalam tanaman ada banyak komponen kimia yang dapat digunakan sebagai obat. Pada saat ini, banyak orang kembali menggunakan bahanbahan alam yang dalam pelaksanaannya membiasakan hidup dengan menghindari bahan-bahan kimia sintesis dan lebih mengutamakan bahan-bahan alami. Pengobatan dengan bahan alam yang dapat dipilih sebagai solusi mengatasi penyakit, salah satunya ialah penggunaan ramuan obat berbahan herbal (Kardinan dan Kusuma, 2004). Salah satu tumbuhan mengandung senyawa obat yaitu buah belimbing wuluh $\begin{array}{llll}\text { (Averrhoa bilimbi } & \text { L.). Hal ini }\end{array}$ memungkinkan dilakukannya penelitian dan penelusuran senyawa kimia tentang metabolit sekunder yang terkandung dalam tumbuh-tumbuhan, metode pemisahan, metode analisis, dan uji farmakologinya.

Hasil isolasi metabolit sekunder dapat memberikan informasi kandungan senyawa aktif yang terdapat dalam tumbuhan sebagai obat atau bahan baku obat. Bagian tanaman belimbing wuluh yang digunakan sebagai bahan baku obat adalah buah, bunga dan daun. Kandungan zat kimia terdapat dalam buah belimbing wuluh adalah flavonoid. Bunganya sering digunakan untuk mengobati batuk dan sariawan. Daunnya digunakan untuk menyembuhkan sakit perut, demam, dan encok. Sementara itu, buahnya digunakan untuk mengobati gusi berdarah, meredakan batuk, membasmi jerawat dan mengatasi tekanan darah tinggi (Adji, 2004).
Berdasarkan penelitian telah dilakukan oleh (Zakaria, dkk, 2007) dan (Chandra, dkk, 2011) menyatakan bahwa buah belimbing wuluh memiliki aktivitas antibakteri pada bakteri Gram positif Staphylococcus epidermidis, Bacillus cereus, Corynebacterium diphtheriae dan Kocuria rhizophilla serta pada bakteri Gram negatif yaitu Salmonellaparatyphi. Sedangkan menurut penelitian (Qurrotu, 2008) menunjukkan bahwa ekstrak kasar buah belimbing wuluh (Averrhoa bilimbi L.) berpotensi sebagai anti bakteri terhadap bakteri Staphylococcus aureus dan Escherichia coli. Dimana diduga golongan senyawa aktif dari ekstrak buah belimbing wuluh yang berpotensi sebagai antibakteri adalah flavonoid.

Berdasarkan hal tersebut maka perlu dilakukan penelitian ini dengan mengisolasi dan mengidentifikasi senyawa flavonoid yang terdapat dalam buah belimbing wuluh. Hal ini bertujuan untuk dapat membantu dalam pengembangan ilmu pengetahuan dan studi penelitian selanjutnya.

\section{METODE PENELITIAN}

\section{Bahan}

\section{Bahan uji yang digunakan adalah Buah belimbing wuluh (Averrhoa bilimbi L.).}

Bahan penelitian yang digunakan berderajat tekhnis yaitu akuades $\left(\mathrm{H}_{2} \mathrm{O}\right)$ dan etanol $96 \%\left(\mathrm{C}_{2} \mathrm{H}_{5} \mathrm{OH}\right)$, yang berderajat p.a (Pro.Analysis) yaitu metanol $\left(\mathrm{CH}_{3} \mathrm{OH}\right)$, asam klorida $(\mathrm{HCl})$, kloroform $\left(\mathrm{CHCl}_{3}\right)$, nbutanol $\left(\mathrm{C}_{4} \mathrm{H}_{9} \mathrm{OH}\right)$, asam asetat glasial $\left(\mathrm{CH}_{3} \mathrm{COOH}\right)$, aluminium klorida $\left(\mathrm{AlCl}_{3}\right)$, natrium asetat $\left(\mathrm{CH}_{3} \mathrm{COO} . \mathrm{Na}\right)$, asam borat $\left(\mathrm{H}_{3} \mathrm{BO}_{3}\right)$, magnesium $(\mathrm{Mg})$, amonia $\left(\mathrm{NH}_{4}\right)$ dan silika gel (60 $\left.\mathrm{GF}_{254}\right)$. 


\section{Metode}

\section{Pengambilan Sampel.}

Sampel buah belimbing wuluh (Averrhoa bilimbi L.) diperoleh dari Desa Lolu, Kecamatan Sigi, Kabupaten Sigi Biromaru, Sulawesi Tengah. Identifikasi sampel dilakukan di UPT sumber Daya Hayati, Sulawesi Tengah, Universitas Tadulako.

\section{Ekstraksi sampel (Maserasi).}

Sebanyak 587,82 gram simplisia yang telah halus diekstraksi dengan metode maserasi dengan menggunakan pelarut etanol $96 \%$. Maserasi dilakukan selama 3 x 24 jam dengan tiap 1 x 24 jam dilakukan pengadukan sehingga semua senyawa organik memungkinkan akan tertarik pada pelarut yang digunakan. Kemudian di saring untuk mendapatkan filtrat atau ekstrak cair, lalu filtrat yang diperoleh di pekatkan dengan rotary evaporatorpada suhu $70^{\circ} \mathrm{C}$ dengan kecepatan 100 rpm sampai didapatkan ekstrak kental.

\section{Isolasi Senyawa Flavonoid.}

Pada tahap ini dilakukan pemisahan senyawa flavonoid dengan KLT analitik, kromatografi vakum cair dan KLT preparatif. KLT analitik bertujuan untuk mencari eluen terbaik untuk pemisahan senyawa flavonoid dari ekstrak buah belimbing wuluh(Averrhoa bilimbiL.) hasil yang diperoleh digunakan sebagai eluen untuk KLT preparatif.

1. KLT Analitik. Menotolkan ekstrak kental pada plat KLT menggunakan pipa kapiler yang sebelumnya plat telah dibuat garis batas atas $1 \mathrm{~cm}$ dan batas bawah $1 \mathrm{~cm}$ dengan ukuran plat KLT silika gel $60 \mathrm{~F}_{254}$ yang berukuran 2 x 10 cm. Dalam Markham (1988) disebutkan bahwa pada umumnya eluen yang digunakan untuk memisahkan komponen-komponen dalam bahan alam yang diduga mengandung flavonoid adalah campuran n-butanol : asam asetat glasial : air (BAA) (4:1:5), BAA (6:1:3) dan metanol : kloroform (7:3), (6:4), (5;5), (4:6), (3:7), (2:8), (1:9), (1:19), dan (1:29) masing- masing sebanyak $20 \mathrm{~mL}$. Hasil pemisahan KLT analitik berupa Bercak yang tampak diperiksa dengan lampu UV $245 \mathrm{~nm}$ dan $366 \mathrm{~nm}$ kemudian diidentifikasi menggunakan uap amonia. Lempeng KLT yang sudah kering diletakkan diatas gelas kimia yang berisi amonia. Bercak yang terbentuk diperiksa dengan lampu UV pada panjang gelombang $245 \mathrm{~nm}$ dan 366 nmkemudian disemprot dengan pereaksi $\mathrm{AlCl}_{3}$ lalu diperiksa kembali dengan lampu UV $254 \mathrm{~nm}$ dan $266 \mathrm{~nm}$. Eluen yang memberikan pemisahan yang paling baik nantinya akan digunakan dalam pemisahan kromatografi vakum cair dan KLT preparatif.

2. Kromatografi Vakum Cair. Kolom kromatografi vakum cair dibersihkan, kemudian dipasang tegak lurus. Adsorben (silika gel $60 \quad \mathrm{GF}_{254}$ ) dimasukkan dalam kolom lalu ditambah cairan pengelusi awal, sambil pompa vakum dijalankan untuk memadatkan atau memampatkan adsorben (silika gel)(Rahim dkk, 2012). 
Dari hasil KLT analitik yang membuktikan bahwa positif terdapat senyawa flavonoid pada ekstrak kental tersebut, maka selanjutkan dilakukan pemisahan dengan metode $\mathrm{KVC}$, dimana 4 gram sampel ekstrak kental dibuatkan dalam bentuk suspensi dengan cara melarutkan dalam eter secukupnya dan ditambahkan silika gel secukupnya. Fase diam berupa silikagel dimasukkan kedalam kolom lalu dihisap dengan cara menggunakan pompa vakum hingga mampat. kemudian memasukkan cairan pengelusi yaitu campuran n-butanol : asam asetat glasial : air dengan perbandingan berturut-turut $\quad(12 ; 1), \quad(8: 1), \quad(6: 1)$, (6:1:1), (6:1:1), (6:1:2), (6:1:4) dan campuran metanol : air (1:1) masingmasing sebanyak $25 \mathrm{~mL}$. Dijalankan pompa vakum hingga eluen turun mengelusi komponen kimia dan eluat (fraksi ) yang keluar ditampung.

Masing-masing fraksi di totolkan pada lempeng KLT untuk melihat pemisahan Bercak yang baik dan menunjukkan adanya senyawa flavonoid. Kemudian Bercak tersebut diambil untuk dilanjutkan ke tahap isolasi menggunakan KLT preparatif.

\section{Isolasi Senyawa Flavonoid dengan KLT Preparatif.}

Fraksi-fraksi yang didapatkan dari hasil KVC memiliki warna dan spot yang hampir sama atau mirip, diambil untuk di KLT preparatif. Kemudian fraksi-fraksi ditotolkan secara horizontal sepanjang plat dengan menggunakan pipet mikro pada jarak $1 \mathrm{~cm}$ dari garis bawah dan dari $1 \mathrm{~cm}$ garis atas sehingga membentuk pita. Lalu dibiarkan plat KLT terelusi pada chamber yang berisi eluen n-butanol: asam asetat glasial : air (6:1:3) sebanyak $20 \mathrm{~mL}$. Hasil KLT diangin-anginkan dan diamati di bawah sinar UV pada panjang gelombang $245 \mathrm{~nm}$ dan $366 \mathrm{~nm}$. Bercak hasil KLT (pita) dikerok dan dilarutkan dengan pelarut metanol secukupnya, kemudian disentrifuge untuk mengendapkan silikanya, sehingga diperoleh supernatan. Supernatan diuapkan hingga kering pada suhu $25^{\circ} \mathrm{C}$ lalu ditimbang dan didapatkan isolat.

\section{Identifikasi Senyawa Flavonoid.}

Isolat dianalisis secara fisika menggunakan spektrofotometer UV-Vis dan secara kimia menggunakan uji warna (pereaksi geser) yaitu aluminium klorida, natrium hidroksida, asam asetat, dan asam borat.

\section{HASIL DAN PEMBAHASAN}

Hasil pemisahan KLT Analitik menunjukkan bahwa eluen dari campuran metanol : klorofrom (7:3), (6:4), (5:5), (4:6), $(3: 7)$, (2:8) dan $(1 ; 9)$ belum dapat memisahkan komponen-komponen senyawa flavonoid yang terkandung dalam buah belimbing wuluh, dapat dilihat pada gambar 1 dan 2. Eluen campuran n-butanol: asam asetat glasial : air (BAA) dengan perbandingan (4:1:5) dan (6:1:3) dapat memisahkan komponen senyawa flavonoid dalam ekstrak etanol buah belimbing wuluh., dapat dilihat pada gambar 3 dan 4 . Eluen campuran BAA (4:1:5) mampu menghasilkan 4 bercak namun kurang terpisah baik dan eluen campuran BAA 
(6:1:3) mampu menghasilkan 3 bercak yang terpisah baik.

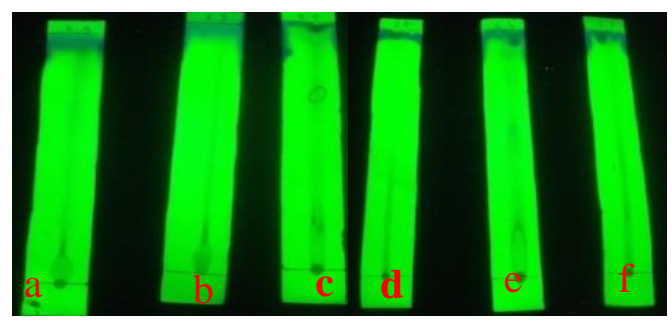

Gambar 1. Profil KLT dibawah lampu UV $254 \mathrm{~nm}$ menggunakan pelarut metanol : kloroform dengan variasi konsentrasi a(7:3), b(6:4), c (5:5), d (4:6), e (3:7), dan f (2:8)

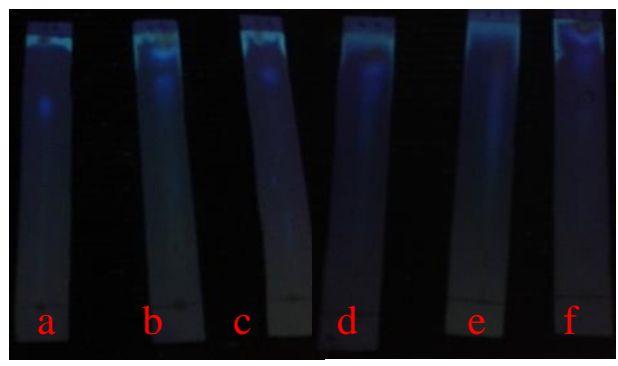

Gambar 2. Profil KLT A dibawah lampu UV $366 \mathrm{~nm}$ menggunakan pelarut metanol : kloroform dengan variasi konsentrasi a(7:3), b(6:4), c (5:5), d (4:6), e (3:7), dan f (2:8)
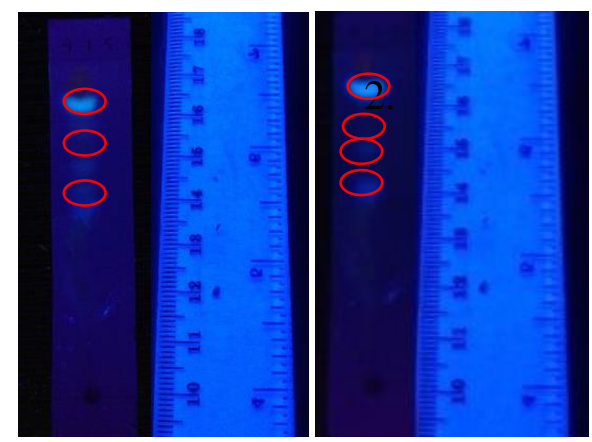

Gambar 3. Kromatogram ekstrak etanol 96 $\%$ buah belimbing wuluh fase diam silika gel, fase gerak BAA (4:1:5\%), Jarak migrasi 7,5 cm, 1(dibawah lampu UV 366 $\mathrm{nm}), 2$ (setelah uap amonia)

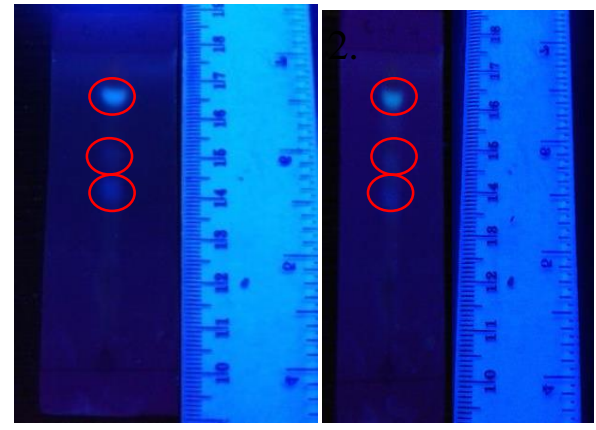

Gambar4. Kromatogram ekstrak etanol $96 \%$ buah belimbing wuluh fase diam silika gel, fase gerak BAA (6:1:3 \%), Jarak migrasi 7,5 cm, 1(dibawah lampu UV $366 \mathrm{~nm}), 2$ (setelah uap amonia)

Pemisahan senyawa-senyawa yang terdapat dalam ekstrak etanol buah belimbing wuluh dilakukan dengan kromatografi vakum cair dengan menggunakan silika gel 60 (GF 254) sebagai fase diam. Sampel sebanyak 4 gram dilarutkan dalam metanol secukupnya lalu ditambahkan dengan fase diam secukupnya dipreabsorbsi dengan silika gel 60 (GF 254) sebanyak 26,68 gram kemudian di elusi dengan eluen BAA dengan perbandingan (12:10, (8:1), (6:1), (6:1:1) sebanyak 2 kali, (6:1:2), (6:1:4) dan metanol : air (1:1). Masing-masing eluat ditampung dalam vial, kemudian diangin-anginkan sehingga didapatkan eluat kental. Pemisahan ini menghasilkan 8 fraksi. Fraksi 3,4,5 memberikan indikasi adanya bercak utama pada hasil profil KLT. Dari hasil profil KLT memberikan 3 jenis bercak yang cukup baik pemisahannya yaitu bercak berwarna biru muda, hijau-kuning dan lembayung gelap. Pengamatan profil KLT dari hasil KVC dengan gabungan Fraksi 3,4, dan 5 dapat dilihat pada gambar 5 

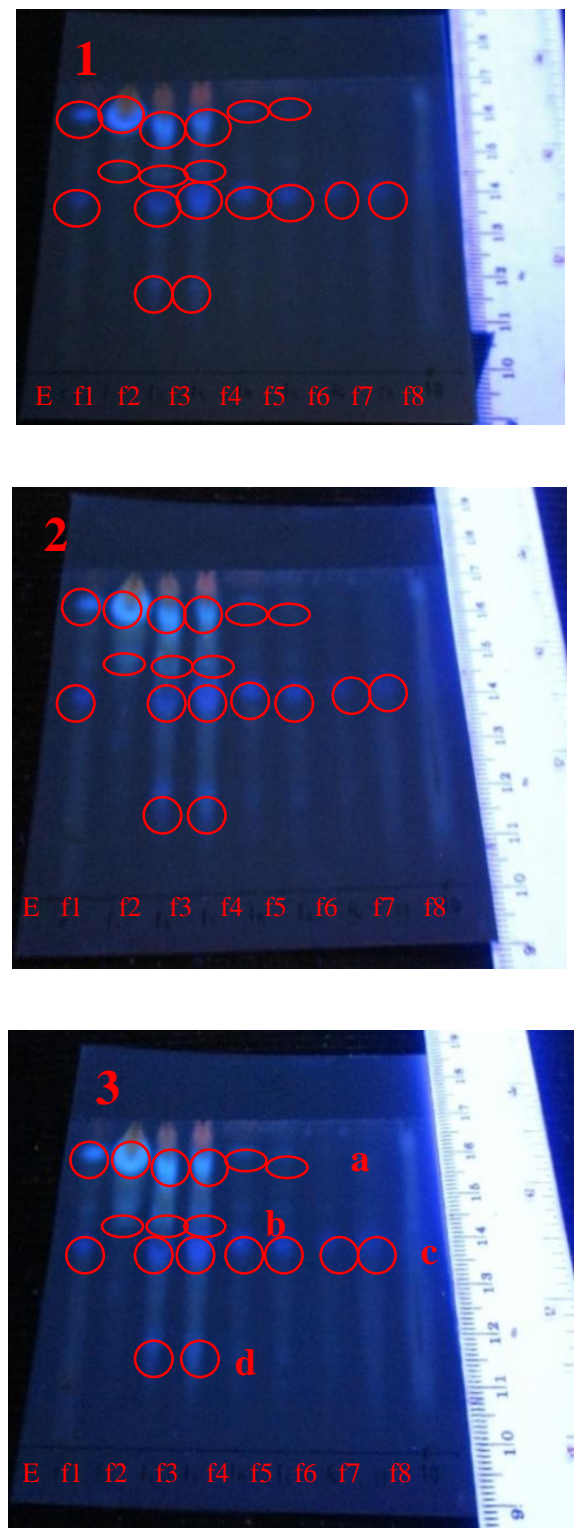

Gambar5. Kromatogram hasil fraksi dengan eluen BAA (12:1), (8:1), (6:1), (6:1:1), (6:1:1), (6:1:2), (6:1:4) dan metanol : Air (1:1), 1 (sebelum di uap amonia), 2 (setelah di uap amonia), dan 3 (setelah di semprot $\left.\mathrm{AlCl}_{3}\right)$.

Ket : a (Bercak berwarna biru muda) $\mathrm{b}$ (Bercak berwarna hijau-kuning) c (Bercak berwarna lembayung gelap)

d (Bercak berwarna lembayung gelap)
Hasil pemisahan dari kromatografi vakum cair yang menghasilkan 3 fraksi (Fraksi 3,4,dan 5) digabung dan dilakukan pemisahan dengan KLT preparatif. Eluen yang digunakan pada KLT preparatif adalah eluen terbaik dari hasil KLT analitik yaitu eluen BAA (6:1:3). Plat yang digunakan adalah plat KLT silika gel 60 PF 254 dengan ukuran 20 x $20 \mathrm{~cm}$. Penggunaan silika gel $\mathrm{PF}_{254}$ memiliki mekanisme secara adsorbsi dan partisi, dimana simbol ' $\mathrm{P}$ ' artinya lapisan untuk preparatif yang di gunakan pada plat Kromatografi Lapis Tipis Preparatif (KLTP) sehingga pita-pita yang nampak pada plat dapat dikeruk. Setelah dilakukan proses elusi pada hasil gabungan fraksi dalam chamber, plat KLTP diamati di bawah lampu UV $366 \mathrm{~nm}$. Pada plat menghasilkan 3 pita. Pita pertama berfluoresensi warna biru muda, pita kedua berfluoresensi warna hijau-kuning dan pita ketiga berfluoresensi warna lembayung gelap. Pita-pita yang dihasilkan kemudian dikerok dan dilarutkan dalam metanol. Kemudian di sentrifuge untuk mengendapkan silika gel atau memisahkan silika gel dan supernatan yang didapatkan sehingga diperoleh isolat. Isolat yang diperoleh diidentifikasi menggunakan spektrofotometri UV-Vis dengan menggunakan pereaksi geser.

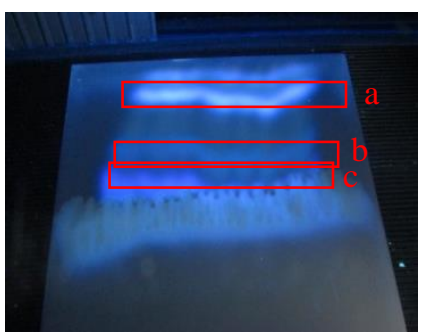

Gambar 6. KLT Preparatif dibawah366 nm 
Ket :
a. Isolat 1 berwarna hijau-biru
b. Isolat 2 berwarna hijau-kuning
c. Isolat 3 berwarna lembayung gelap

Dari data spektrum pada tabel 1 . Didapatkan senyawa flavonoid dari hasil KLT preparatif adalah isolat 1 dan 3. Isolat 2 bukan merupakan senyawa flavonoid karena setelah ditambahkan pereaksi geser (metanol dan $\mathrm{AlCl}_{3}$ ), (metanol, $\mathrm{HCl}$, dan $\mathrm{AlCl}_{3}$ ), (metanol dan natrium asetat), dan (metanol, natrium asetat, dan asam borat) tidak memiliki panjang gelombang maksimum dan panjang gelombang maksimum pada penambahan pereaksi $\mathrm{NaOH}$ tidak sesuai dengan data literatur. Sehingga diperkirakan isolat-isolat tersebut merupakan senyawa polifenol yang lain.

Tabel 1. Panjang gelombang maksimum dari bercak KLT preparative dibawah sinar UV 245 dan $366 \mathrm{~nm}$ serta penambahan pereaksi geser.

\begin{tabular}{|c|c|c|c|c|c|c|}
\hline \multirow[b]{2}{*}{ Isolat } & \multicolumn{6}{|c|}{ Panjang gelombang maksimum $(\mathrm{nm})$ dengan penambahan pereaksi geser } \\
\hline & $\mathrm{CH}_{3} \mathrm{OH}$ & $\begin{array}{c}\mathrm{CH}_{3} \mathrm{OH} \\
+ \\
\mathrm{NaOH}\end{array}$ & $\begin{array}{c}\mathrm{CH}_{3} \mathrm{O} \\
\mathrm{H}+ \\
\mathrm{AlCl}_{3}\end{array}$ & $\begin{array}{c}\mathrm{CH}_{3} \mathrm{OH} \\
+ \\
\mathrm{AlCl}_{3} / \mathrm{HCl}\end{array}$ & $\begin{array}{c}\mathrm{CH}_{3} \mathrm{OH} \\
+ \\
\mathrm{CH}_{3} \mathrm{COO} . \\
\mathrm{Na}\end{array}$ & $\begin{array}{c}\mathrm{CH}_{3} \mathrm{OH} \\
+ \\
\mathrm{CH}_{3} \mathrm{COO} . \mathrm{Na} \\
+\mathrm{H}_{3} \mathrm{Bo3}\end{array}$ \\
\hline 1 & 305 & 354 & 311 & 307 & 320 & 315 \\
\hline & 212 & 258 & 224 & 226 & 246 & 226 \\
\hline 2 & 328 & 397 & - & - & - & - \\
\hline & 305 & 396 & - & - & - & - \\
\hline 3 & 314 & 369 & 316 & - & 323 & 323 \\
\hline & 249 & 256 & 314 & 278 & 229 & 260 \\
\hline
\end{tabular}


Hamdana et al./Galenika Journal of Pharmacy

(A)

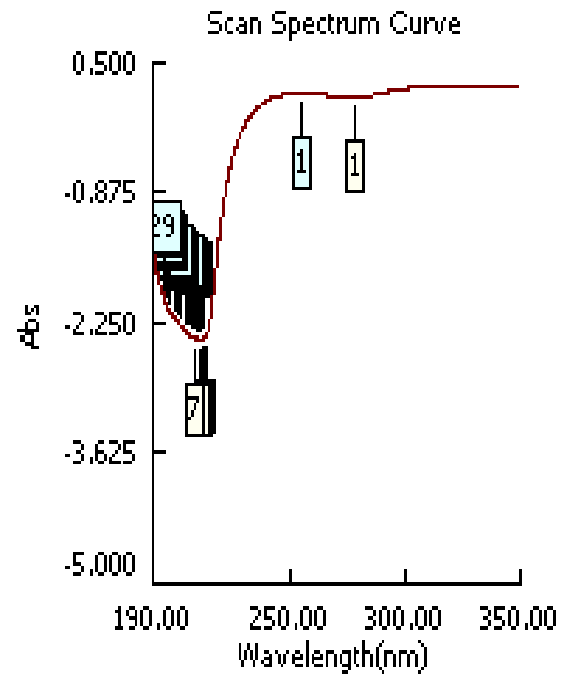

(C)

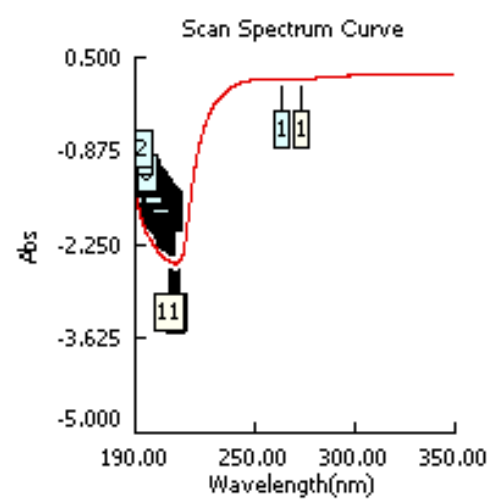

(E)

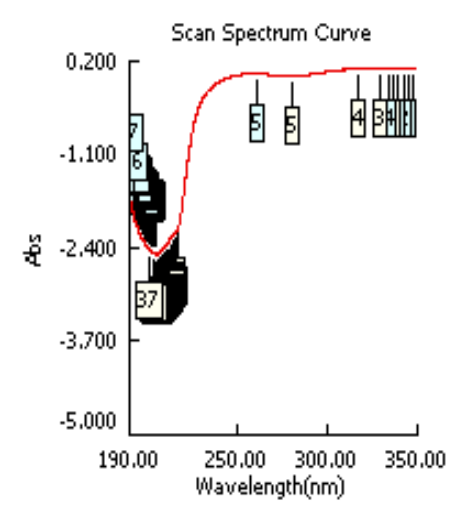

(B)

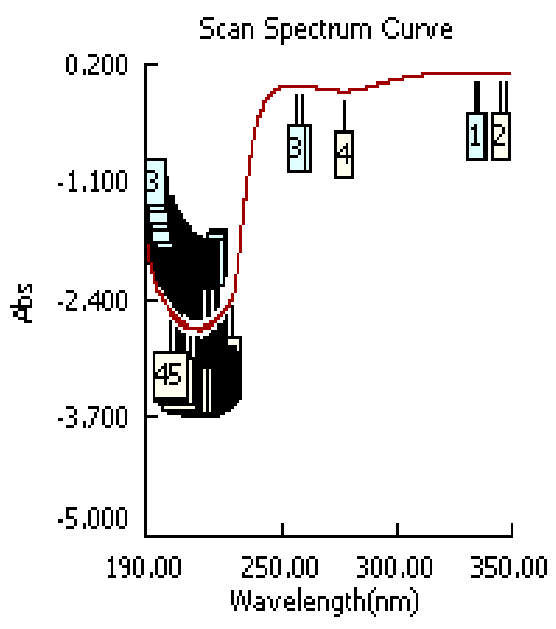

(D)

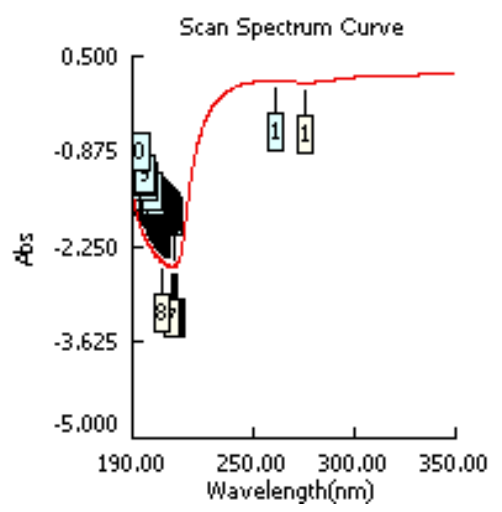

(F)

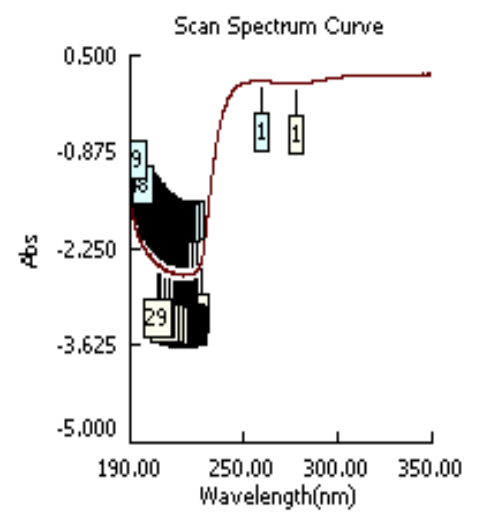

Gambar 7. Spektrum UV hasil senyawa isolat 1 dalam Metanol (A), $\mathrm{NaOH}(\mathrm{B}), \mathrm{AlCl}_{3}(\mathrm{C})$, $\mathrm{AlCl}_{3}+\mathrm{HCl}(\mathrm{D})$, Natrium Asetat (E), dan Natrium Asetat + Asam Borat (F). 
Tabel 2. Interpretasi perubahan panjang gelombang dari isolat 1 dengan penambahan pereaksi geser.

\begin{tabular}{|c|c|c|c|c|c|}
\hline \multirow[t]{2}{*}{ Perlakuan } & \multicolumn{2}{|c|}{$\begin{array}{c}\text { Panjang } \\
\text { Gelombang } \\
\lambda \text { maks }(\mathrm{nm})\end{array}$} & \multicolumn{2}{|c|}{$\begin{array}{c}\text { Geseran } \\
\text { panjang } \\
\text { Gelombang } \\
\lambda \text { maks(nm) }\end{array}$} & \multirow[t]{2}{*}{ Dugaan substitusi } \\
\hline & Pita I & Pita II & Pita I & Pita II & \\
\hline Isolat $+\mathrm{CH}_{3} \mathrm{OH}$ & 305 & 212 & - & - & \\
\hline $\begin{array}{l}\text { Isolat }+\mathrm{CH}_{3} \mathrm{OH}+ \\
\mathrm{NaOH}\end{array}$ & 354 & 258 & +49 & +46 & $4^{\prime}-\mathrm{OH}$ \\
\hline $\begin{array}{l}\text { Isolat }+\mathrm{CH}_{3} \mathrm{OH}+ \\
\mathrm{AlCl}_{3}\end{array}$ & 311 & 224 & +6 & +12 & $\begin{array}{l}\text { Mungkin } o \text {-diOH pada cincin } \\
\mathrm{A} ; 5-\mathrm{OH} \text { (isoflavon) }\end{array}$ \\
\hline $\begin{array}{l}\text { Isolat }+\mathrm{CH}_{3} \mathrm{OH}+ \\
\mathrm{AlCl}_{3}+\mathrm{HCl}\end{array}$ & 307 & 226 & +2 & +14 & $\begin{array}{l}\text { Mungkin } o \text {-diOH pada cincin } \\
\text { A; } 5-\mathrm{OH} \text { (isoflavon) }\end{array}$ \\
\hline $\begin{array}{l}\text { Isolat }+\mathrm{CH}_{3} \mathrm{OH}+ \\
\mathrm{CH}_{3} \mathrm{COO} \cdot \mathrm{Na}\end{array}$ & 320 & 246 & +15 & +20 & 7-OH \\
\hline $\begin{array}{l}\text { Isolat }+\mathrm{CH}_{3} \mathrm{OH}+ \\
\mathrm{CH}_{3} \mathrm{COO} \cdot \mathrm{Na}+\mathrm{H}_{3} \mathrm{BO}_{3}\end{array}$ & 315 & 226 & +10 & +14 & $\begin{array}{l}o \text {-diOH pada cincin A }(6,7 \\
\text { atau } 7,8)\end{array}$ \\
\hline
\end{tabular}

Hasil pemeriksaan pendahuluan terhadap isolat 1 mengarah dugaan pada isolfavon yang tak mengandung $5-\mathrm{OH}$ bebas. Hal ini didasarkan pada uji pendahuluan dengan mengunakan KLT menghasilkan bercak warna biru muda sebelum diberi uap amonia dan tetap berwarna biru muda setelah di beri uap amonia.

Pada identifikasi menggunakan spektrofotometer UV-Vis dengan menggunakan pereaksi geser, interpretasi perubahan panjang gelombang dari isolat 1 dengan penambahan $\mathrm{NaOH}$ menyebabkan pergerseran panjang gelombang batokromik pada pita I sebesar $49 \mathrm{~nm}$ dan pita II sebesar $46 \mathrm{~nm}$ yang menunjukkan bahwa adanya gugus 4'-OH , jenis senyawa flavonoid yang diduga adalah flavon dan flavonol. Penambahan $\mathrm{AlCl}_{3}$ menyebabkan pergeseran pada pita I sebesar $6 \mathrm{~nm}$ dan pergeseran pada pita II sebesar $12 \mathrm{~nm}$, sedangkan penambahan $\mathrm{AlCl}_{3}+\mathrm{HCl}$ menghasilkan pergeseran pada pita I sebesar $2 \mathrm{~nm}$ dan pada pita II terjadi pergeseran sebesar $14 \mathrm{~nm}$. Hal ini menunjukkan kemungkinkan adanya gugus $o$-diOH pada cincin A dan 5-OH (isoflavon). Jenis senyawa yang diduga adalah isoflavon. Penambahan Natrium Asetat menyebabkan pergeseran panjang gelombang yang panjang pada pita I sebesar $15 \mathrm{~nm}$ dan pita II sebesar $20 \mathrm{~nm}$, hal ini menunjukkan adanya gugus 7-OH. Penambahan Natrium Asetat + Asam borat menghasilkan pergeseran panjang gelombang lebih kecil pada pita I sebesar 10 dan pita II sebesar 15. Hal ini menunjukkan adanya gugus $o$-diOH pada cincin A $(6,7$ atau 7,8). Jenis senyawa yang diduga adalah isoflavon, flavanon dan dihidroflavon. 
Dari data di atas dapat diduga bahwa isolat 1 adalah senyawa isoflavon dengan

(A)

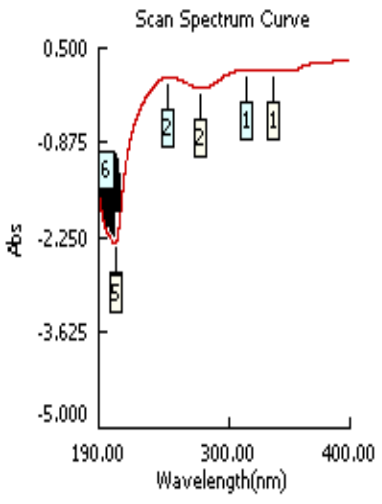

(C)

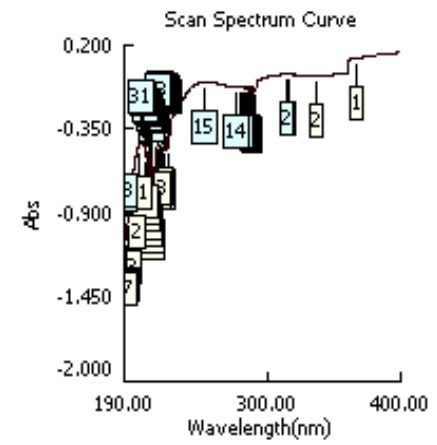

(E)

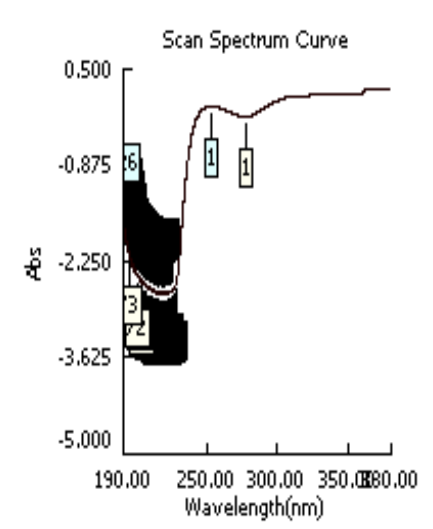

gugus $\mathrm{OH}$ pada posisi $6,7,4$ ' serta gugus odiOH pada cincin $\mathrm{A}$.

(B)

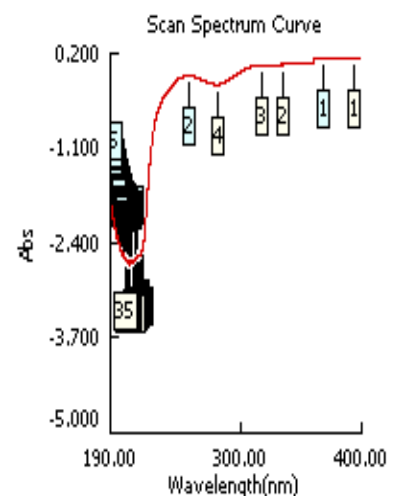

(D)

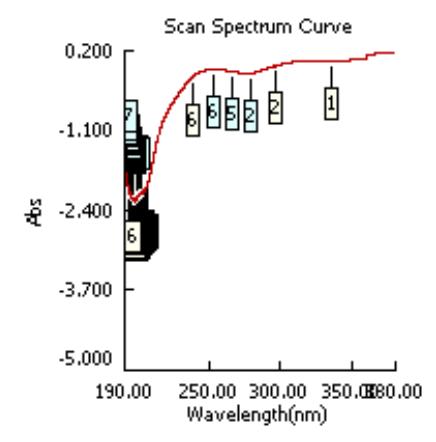

(F)

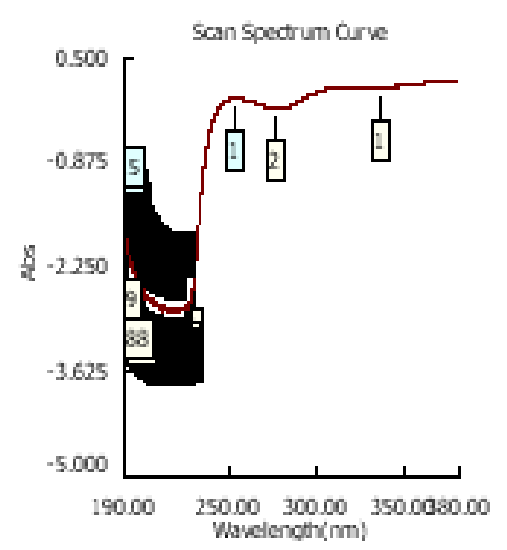

Gambar 8. Spektrum UV hasil senyawa isolat 3 dalam Metanol (A), $\mathrm{NaOH}(\mathrm{B}), \mathrm{AlCl}_{3}$ (C), $\mathrm{AlCl}_{3}+\mathrm{HCl}(\mathrm{D})$, Natrium Asetat (E), dan Natrium Asetat + Asam Borat(F) 
Tabel 3. Interpretasi perubahan panjang gelombang dari isolat 3 dengan penambahan pereaksi geser.

\begin{tabular}{|c|c|c|c|c|c|}
\hline \multirow[t]{2}{*}{ Perlakuan } & \multicolumn{2}{|c|}{$\begin{array}{c}\text { Panjang } \\
\text { Gelombang } \\
\lambda \text { maks }(\mathbf{n m})\end{array}$} & \multicolumn{2}{|c|}{$\begin{array}{c}\text { Geseran } \\
\text { panjang } \\
\text { Gelombang } \\
\lambda \text { maks(nm) }\end{array}$} & \multirow[t]{2}{*}{ Dugaan substitusi } \\
\hline & Pita I & Pita II & Pita I & Pita II & \\
\hline Isolat $+\mathrm{CH}_{3} \mathrm{OH}$ & 314 & 249 & - & - & \\
\hline $\begin{array}{c}\text { Isolat }+\mathrm{CH}_{3} \mathrm{OH}+ \\
\mathrm{NaOH}\end{array}$ & 369 & 256 & +55 & +7 & 4'-OH \\
\hline $\begin{array}{c}\text { Isolat }+ \text { Metanol + } \\
\mathrm{AlCl}_{3}\end{array}$ & 316 & 314 & +2 & +58 & $\begin{array}{l}\text { Mungkin } o \text {-diOH pada } \\
\text { cincin A ; Mungkin 3-OH } \\
\text { (dengan atau tanpa 5-OH) }\end{array}$ \\
\hline $\begin{array}{c}\text { Isolat }+\mathrm{CH}_{3} \mathrm{OH} 1+ \\
\mathrm{AlCl}_{3}+\mathrm{HCl}\end{array}$ & - & 278 & - & +29 & $\begin{array}{l}o \text {-diOH pada cincin A }(6,7 \\
\text { dan } 7,8)\end{array}$ \\
\hline $\begin{array}{c}\text { Isolat }+\mathrm{CH}_{3} \mathrm{OH}+ \\
\mathrm{CH}_{3} \mathrm{COO} \cdot \mathrm{Na}\end{array}$ & 323 & 229 & +9 & -20 & 7-OH \\
\hline $\begin{array}{c}\text { Isolat }+\mathrm{CH}_{3} \mathrm{OH}+ \\
\mathrm{CH}_{3} \mathrm{COO} \cdot \mathrm{Na}+\mathrm{H}_{3} \mathrm{BO}_{3}\end{array}$ & 323 & 260 & +9 & -11 & $\begin{array}{l}o \text {-diOH pada cincin A }(6,7 \\
\text { atau } 7,8)\end{array}$ \\
\hline
\end{tabular}

Hasil pemeriksaan pendahuluan terhadap isolat 3 mengarah dugaan yang biasanya flavon atau flavonol tersulih pada 3-O mempunyai 5-OH tetapi tanpa 4'-OH bebas, beberapa 6- atau 8-OH flavon dan flavonol tersulih pada 3-O serta mengandung 5-OH. Hal ini didasarkan pada uji pendahuluan dengan mengunakan KLT menghasilkan bercak lembayung gelap sebelum diberi uap amonia dan tetap berwarna lembayung gelap setelah di beri uap amonia.

Pada identifikasi menggunakan spektrofotometer UV-Vis dengan menggunakan pereaksi geser, interpretasi perubahan panjang gelombang dari isolat 3 dengan penambahan $\mathrm{NaOH}$ menyebabkan pergerseran panjang gelombang pada pita I sebesar $55 \mathrm{~nm}$ dan pita II sebesar $7 \mathrm{~nm}$ yang menunjukkan adanya gugus 4'-OH. Jenis senyawa yang diduga adalah flavon dan flavonol.

Penambahan $\mathrm{AlCl}_{3}$ menyebabkan pergeseran panjang gelombang pada pita I sebesar $2 \mathrm{~nm}$ (penambahan lebih kecil) yang menunjukkan kemungkinan adanya gugus $o$-di $\mathrm{OH}$ pada cincin A sedangkan pergeseran panjang gelombang pita II sebesar $58 \mathrm{~nm}$ (pergeseran lebih besar) yang menunjukkan kemungkinan adanya gugus 3$\mathrm{OH}$ (dengan atau tanpa 5-OH). Jenis senyawa yang diduga adalah flavon dan flavonol. 


\begin{abstract}
Penambahan Natrium Asetat menyebabkan pergeseran panjang gelombang pada pita I sebesar $9 \mathrm{~nm}$ dan pita II sebesar $20 \mathrm{~nm}$ yang menunjukkan adanya gugus 7-OH. Hal yang sama juga ditunjukkan pada penambahan Natrium Asetat + Asam borat. Pergeseran panjang gelombang pada pita I sebesar 9 dan pita II sebesar 11 yang menunjukkan adanya gugus $o$-diOH pada cincin A $(6,7$ atau 7,8$)$. Jenis senyawa yang di duga adalah flavon dan flavonol.
\end{abstract}

\section{DAFTAR PUSTAKA}

Adithya, Yonahes, Koirewoan, dkk. (2010). Isolasi Dan Identifikasi Senyawa Flavonoid Dalam Daun Beluntas (PlucheaIndicaL.). Program Studi Farmasi FMIPA UNSRAT Manado, 95115.

Chandra, Sreedam, das Shapna, Sultana., Sumon, Roy., Sheikh, Sayed, Hasan. (2011). Antibacterial and cytotoxic activities of methanolic extracts of leaf and fruit parts of the plant Averrhoa bilimbi (Oxalidaceae). Department of Pharmacy. Southeast University, Dhaka, Bangladesh Department of Pharmaceutical Technology, University of Dhaka, Dhaka, ISSN: 2152-649X. Bangladesh.

Harsodjo S.(2003). Isolasi Dan Identifikasi Flavonoid Pada Daun Katu (Sauropus androgynous (L.) Merr). Badan Pengawas Obat dan Makanan, Departemen Kesehatan RI. Jakarta 10560. Indonesia; Jurusan Farmasi,
Dari data di atas, dapat diduga bahwa isolat 3 adalah senyawa flavon dengan gugus $\mathrm{OH}$ pada posisi 5,6,7,4' serta gugus odiOH pada cincin A.Pada data isolat telah didapatkan senyawanya, namun perlu adanya penelitian lebih lanjut untuk penentuan struktur flavonoid dari buah Belimbing wuluh (Averrhoa bilimbi L.) dengan metode spektroskopi lainnya seperti NMR, FTIR, dan MS.

FMIPA, Institut Sains dan Teknologi Nasional, MAKARA SAINS, Vol. 7, No. 2, Agustus. Jakarta.

Khoirina, Dwi, Nugrahaningtyas.,Sabirin, Matsjeh., Tutik, Dwi, Wahyuni. 2005. Isolasi dan Identifikasi Senyawa Flavonoid dalam Rimpang Temu Ireng (Curcuma aeruginosa Roxb.). Jurusan Kimia FMIPA Universitas Sebelas Maret (UNS), Surakarta.

Markham, K.R. (1988). Cara Mengidentifikasi Flavonoid. Penerjemah Padmawinata, K. Penerbit ITB. Bandung.

Pino, J.A., Marbot, R., \& Bello, A. (2004). Volatile Components of Averrhoa bilimbi L. Fruit Grown in Cuba. Journal of Essential Oil Research: JEOR, (Online), (http://findarticles.com/p/articles/miqa 4091/is200405/ai n94520 07, diakses 15 November 2013). 
Qurrotu A.(2008). Uji Efektivitas Ekstrak Kasar Senyawa Anti Bakteri Pada Buah Belimbing Wuluh (Averrhoa bilimbi L.) dengan Variasi Pelarut (Skripsi), Jurusan Kimia, Fakultas Sains dan Teknologi, Universitas Islam Negeri (UIN) Malang.

Rahim, A., Alam, G., Agustina, R., dan Rusydi, M. (2012). Skrining Toksisitas Ekstrak Herba Bandotan (Ageratum conyzoides L) dengan Metode Brine Shrimp Lethality Test. Majalah Farmasi dan Farmakologi, Vol. 16(2): 99 - 106.

Rahmawan R. (2008). Isolasi Dan Identifikasi Flavonoid Dari Daun Dewandaru (Eugenia uniflora L.) (Skripsi). Fakultas Farmasi Universitas Muhammadiyah, Surakarta.

Sastrohamidjojo, H.(2007). Dasar-Dasar Spektrosfotokopi, edisi kedua, cetakan kedua. Penerbit Liberty : Jogjakarta.

Sastrohamidjojo, H. (1996). Sintesis Bahan Alam. Gadjah Mada University Press. Yogyakarta.

Yohanes, Fatimawali, Weny, Indayang, Wiyono. (2013) .Isolasi Dan Identifikasi Senyawa Flavonoid Dalam Daun Beluntas (PlucheaIndicaL.). Program Studi Farmasi Fmipa Unsrat Manado.

Zakaria, Z.A,. H. Zaiton., E. F. P., Henie., A. M., Mat Jains \& E. N.H. Engka Zainuddin. (2007). In Vitro Antibacterial Activity of Averrhoa bilimbi L. Leaves and Fruits Extracts. International Journal of Tropical Medicine 293: 96-100. 